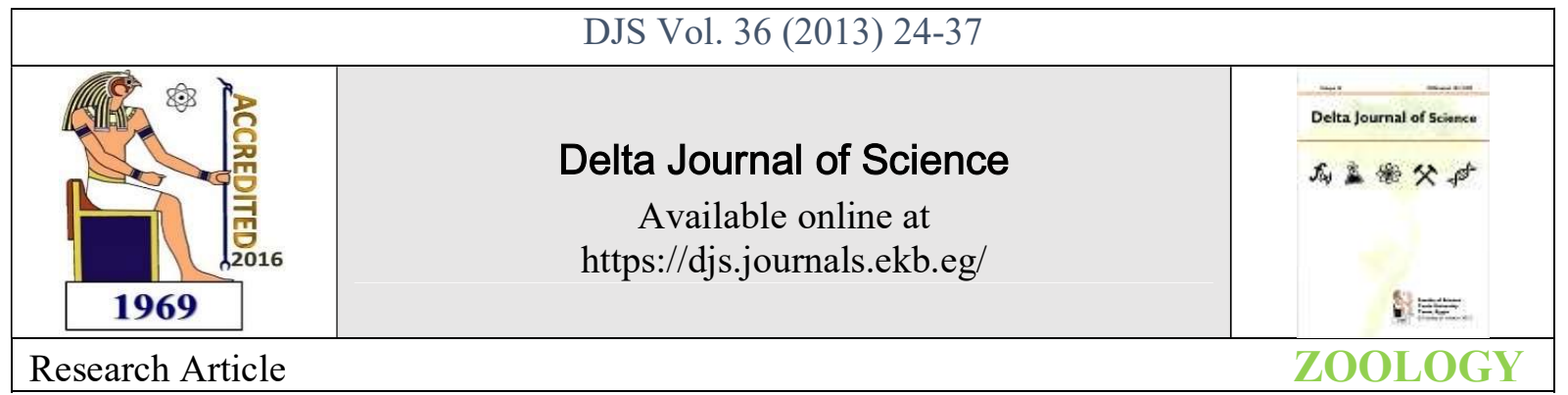

\title{
Electrophysiological protective and therapeutic efficacy of resveratrol against cadmium chloride: An in vitro study
}

\author{
Hagar E. Mohammed ${ }^{\text {a }}$, Sherifa H. Ahmed ${ }^{\mathrm{b}}$, and Zohour I. Nabil ${ }^{\mathrm{c}}$. \\ a Geological and biological Department, Faculty of Education, Suez Canal University, Al-Arish, Egypt. \\ b Zoology Department, Faculty of Applied Sciences, Port Said University, Port Said, Egypt. \\ c Zoology Department, Faculty of Science, Suez Canal University, Ismailia 41522, Egypt.
}

\begin{abstract}
Resveratrol (trans-3,4',5-trihydroxystilbene- RES), is a natural antioxidant found in various fruits and vegetables and is abundant in grapes. It has beneficial effects against coronary heart diseases. This study aims to explore the protective and therapeutic effects of resveratrol on cadmium chloride induced toxicity on isolated toad's hearts. Electrocardiogram (ECG) was recorded before and after direct perfusion of cadmium chloride $\left(\mathrm{CdCl}_{2}\right)$ and resveratrol. Application of $\mathrm{CdCl}_{2}(2 \mathrm{mM} / \mathrm{L})$ into isolated toad's heart significantly decreased the heart rate (HR) accompanied by an elongation in the conduction time (P-R interval), while a non significant decrease of the ventricular contraction (R-wave amplitude) was observed within minutes (5-30 min) of $\mathrm{CdCl}_{2}$ application into isolated toad's. Pretreatment of isolated toad's hearts with RES $(21 \mu \mathrm{M} / \mathrm{L})$ five min before $\mathrm{CdCl}_{2}$ application abolished the severe bradycardia and negative inotropic effect induced by $\mathrm{CdCl}_{2}$, this was accompanied by improvement of cardiac disorders induced by this toxic heavy metal. While, post treatment of RES after appearance of cardiac abnormalities induced by $\mathrm{CdCl}_{2}$ didn't affect these induced disorders. In conclusion, the obtained investigation indicates that RES could serve as a protective agent against some of acute $\left(\mathrm{CdCl}_{2}\right)$ toxicity on isolated toad's heart than more that its therapeutic efficacy. However, low level of resveratrol at was not effective in preventing either neither sever bradycardia nor in reducing ventricular dysfunction induced by cadmium.
\end{abstract}

Keywords: Resveratrol; cadmium toxicity; Cardiac muscle; Electrophysiology

Abbreviation: cardiovascular diseases, CVDs; cadmium chloride, $\mathrm{CdCl}_{2}$; resveratrol, RES; purkinje-ventricular junction, PVJ; C-domain of troponin $\mathrm{C}, \mathrm{cCTnC}$; epigallocatechin gallate, EGCg; glutathione, GSH, atrioventricular node, AVN; nitric oxide, NO.

\section{INTRODUCTION}

There has been increasing interest in the potential adverse cardiovascular effects of environmental exposures, including heavy metals (Weinhold, 2004; Bhatnagar, 2006; Houston, 2007). Cadmium is a ubiquitous environmental toxin which may plausibly contribute to cardiovascular disease (CVDs), although existing literature is limited. Today CVDs are the killer number one worldwide. In 2004, an estimated 17.1 million people died due to CVDs and this number will further increase to an estimated 23.6 million by 2030 (Messner and Bernhard, 2010).

The cardiovascular effects of $\mathrm{Cd}^{2+}$ have been demonstrated-in vitro, in an experimental animal models
(Sarkar et al., 1995; Satarug et al., 2006), and in human studies-that $\mathrm{Cd}^{2+}$ causes atherosclerosis (Messner and Bernhard, 2010), edema and hypertension (Prozialeck et al., 2006). In vitro studies, revealed that low level of $\mathrm{Cd}^{2+}$ (below toxic concentrations) may contribute to the initiation of pathophysiological changes in the vessel wall (Bernhard et al., 2006). Previous studies found an association between blood cadmium and peripheral arterial disease (Navas-Acien et al. 2004) and between urinary cadmium and peripheral arterial disease and myocardial infarction (Navas-Acien et al., 2005; Everett and Frithsen, 2008). Cadmium may exert its adverse cardiovascular effects by promoting atherosclerosis and by inducing disadvantageous cardiac functional and metabolic changes (Houtman, 1993). 
Pathogenesis of some CVDs induced by $\mathrm{Cd}^{2+}$ involves damaging cells, their integral proteins, and enzymatic complexes. There are proofs of the $\mathrm{Cd}^{2+}$ toxic action on channel proteins of ventricular myocytes (Wasserstrom and Vites, 1999), respiratory enzymes (Korotkov et al., 2008), and myofibrils (Berwe et al., 1987).

The effect of $\mathrm{Cd}^{2+}$ on the mechanical activity of the heart was studied by several investigators. Kopp et al. (1983) reported depressed myocardiac contractility in rat's heart from $\mathrm{Cd}^{2+}$ fed groups. They also found out that rats exposed to $\mathrm{Cd}^{2+}$ in drinking water developed electrocardiographic and biochemical changes in the myocardium as well as impairment of the functional status of the heart. Likewise, Nabil et al. (2002) showed that application of $\mathrm{CdCl}_{2}(2 \mathrm{mM})$ decreased the $\mathrm{HR}$ and power of ventricular contraction while increased the conduction time by increasing $\mathrm{P}-\mathrm{R}$ interval either in vitro or in vivo studies.

In addition, Kisling et al. (1993) found that $\mathrm{Cd}^{2+}$ administration caused a reduction in myocardiac contractile performance, slowing of HR and disturbances in metabolism of the heart. On the other hand, the effect of $\mathrm{Cd}^{2+}$ on the atrioventricular node (AVN) which is vital to the normal cardiac function was investigated by Hancox and Levi (1994). They reported that the action potentials recorded by current clamp from AVN were blocked by $\mathrm{Cd}^{2+}(100-200 \mathrm{mM})$. Since $\mathrm{Cd}^{2+}$ produces a reduction in the power of contraction, the conduction at the purkinje-ventricular junction (PVJ) sites was studied by Wiedmann et al. (1996). They proved that the conduction delay at the PVJ sites significantly increased by $\mathrm{Cd}^{2+}$, while some PVJ sites became reversibly non-functional.

$\mathrm{Cd}^{2+}$ was also used as a blocker of voltage-calcium channels to inhibit the stimulating effect of D-decholrinated insecticide on rat myometrial smooth muscle cells (Juberg et al., 1995). It has been reported that the toxicity of $\mathrm{Cd}^{2+}$ is mainly due to increase of membrane lipid peroxidation and peroxidative damage (Chevion, 1991; Moustafa et al., 2000).

With the rapid advances made over the last two decades in biomedical research, there has been an unprecedented interest in unraveling the magical properties of some commonly used natural products. Consequently, a wide variety of natural products are under scrutiny for their clinical potential, both in terms of disease prevention and treatment. One remarkable compound in this list is resveratrol (RES), which is a polyphenol found in various fruits, vegetables, and is abundant in grapes. The root extracts of Polygonum cuspidatum, an important constituent of Chinese and Japanese folk medicine, is also an ample source of RES (Chen et al., 2001).

It has been speculated that RES may act as an antioxidant that modulate nitric oxide (NO) production (Hsieh et al., 1999), modulates vascular cell functions (Wallerath et al., 2002), and inhibits platelet aggregation (Olas et al., 2002). It was also reported that it reduces lipoprotein oxidation (Frankel et al., 1993), and increases high-density lipoprotein cholesterol (Bhat et al., 2001); thereby serving as a cardioprotective agent. In addition, RES exhibits antiinflammatory, cancer chemopreventive and neuroprotective. Although it has a range of biological activities, its underlying mechanism in the protection against coronary heart disease remains unclear.

Risk reduction of cardiovascular events is one of the most well-known health promoting effects of RES. It has been shown that RES may modulate various aspects of cardiovascular diseases, including atherosclerosis, hypertension, ischemia reperfusion injury and heart failure (Huang et al., 2010 \& Thandapilly et al., 2010). The present study was undertaken to elucidate the protective and therapeutic effects of trans-resveratrol on cadmium chlorideinduced cardiac toxicity, for the first time, on isolated toad's hearts.

\section{Materials and Methods}

\section{i-Chemicals and solutions}

RES was purchased from USA from Candlewood Stars Inc /Mega Resveratrol-Danbury, CT, 06810-6257. RES was obtained in a commercially available vegetable capsules at $500 \mathrm{mg}$ polygonum caspidatum per unit, providing 95\% (500mg) RES. The RES stock and working solution (21 $\mu \mathrm{M} / \mathrm{L}$ ) were protected from light by covering the container with aluminum foil. Ringer's solution was used for the isolated heart preparations and composed of $(6.5 \mathrm{gm} / \mathrm{L} \mathrm{NaCl}, 0.14$ $\mathrm{gm} / \mathrm{L} \mathrm{KCl}, 0.2 \mathrm{gm} / \mathrm{L} \mathrm{CaCl}_{2}, 0.2 \mathrm{gm} / \mathrm{L} \mathrm{NaHCO}_{3}, 0.01 \mathrm{gm} / \mathrm{L}$ $\mathrm{NaPO}_{4}$ and $1 \mathrm{gm} / \mathrm{L}$ glucose). Cadmium chloride was purchased from (Riedel-De Haenag- Hannover, Germany) and dissolved in Ringer's solution at a concentration of $2 \mathrm{mM} / \mathrm{L}$ (Nabil et al., 2002).

\section{ii- Cardiac muscle experiments}

Experiments on cardiac muscle were carried out on adult male toads of the species Bufo regularis (35-40g each) with isolated heart preparations. A dose of $2 \mathrm{~m} \mathrm{M}$ of $\mathrm{CdCl}_{2}$ and 21 $\mu \mathrm{M} / \mathrm{L}$ of RES was chosen and directly perfused into isolated heart preparations. ECG data were recorded directly from the surface of the heart according to Nabil et al. (1998) before and after RES and cadmium application. ECG signals were amplified and recorded by the multi-pen-rectilinear recorder (DBE, UK) with paper speeds of 2 and $10 \mathrm{~mm} / \mathrm{sec}$. ECG was taken before any application to serve as self-control. After RES perfusion, signals were recorded each $5 \mathrm{~min}$ for $30 \mathrm{~min}$.

\section{iii- Experimental Design}

Experiments on the cardiac muscle were carried out on the isolated toad's heart preparations. Four groups each of 10 animals except IV group ( 7 animals) were used.

I- Negative control group:- The isolated hearts directly perfused with Ringer's solution.

II- Cadmium chloride treated group:- The isolated hearts directly perfused with $2 \mathrm{mM} \mathrm{CdCl} 2$ to emphasize the cardiac disorders induced by cadmium chloride.

III- Pretreated RES and $\mathrm{CdCl}_{2}$ group:- The isolated toad's hearts pre-treated with RES $(21 \mu \mathrm{M} / \mathrm{L})$ solution for 5 min then they directly perfused with $2 \mathrm{mM} / \mathrm{L} \quad \mathrm{CdCl}_{2}$ lasted the experiment.

IV- $\mathrm{CdCl}_{2}$ pretreated and RES group:- isolated hearts were pre-treated with $\mathrm{CdCl}_{2}(2 \mathrm{mM} / \mathrm{L})$ to induce cardiac abnormalities, then RES $(21 \mu \mathrm{M} / \mathrm{L})$ was added to reveal the therapeutic effect of RES against cadmium inducedcardiotoxicity.

\section{Data analysis}

Responses of $\mathrm{HR}$ and the other electrocardiographic parameters ( $\mathrm{P}-\mathrm{R}$ interval and $\mathrm{R}$ amplitude) before and after treatment with RES were expressed as mean \pm standard error (SE). One-way analysis of variance (ANOVA) was performed to evaluate the eventual significant differences $(\mathrm{P} \leq 0.05)$ in the HR and different ECG parameters between control and treated groups according to Snedecor and Cochran (1980).

\section{RESULTS}

In the present investigation, in vitro experiments were performed to investigate the protective and therapeutic effects of RES against $\mathrm{CdCl}_{2}$ on the cardiac muscle activity through 
studying the influence of RES perfusion before and after $\mathrm{CdCl}_{2}$ application on the ECG of isolated toad hearts. Normal $\mathrm{HR}$ and different ECG parameters were measured from the recorded ECGs of isolated hearts before any treatment to serve as self-control (0-time).

As seen in table 1, application of $\mathrm{CdCl}_{2}$ induced severe bradycardia or -ve chronotropic effect manifested as a decrease of the HR. This was accompanied with an elongation in the P-R interval as shown in Table 2 indicating an increase in conduction time ( + ve dromotropic effect). Regarding the effect of $\mathrm{CdCl}_{2}$ on the cardiac contractility, the amplitude of $\mathrm{R}$ wave decreased at 25 and $30 / \mathrm{min}$ after $\mathrm{CdCl}_{2}$ application reflecting a negative inotropic effect as demonstrated in table 3. All the above mentioned changes in the HR and ECG parameters were statistically significant in comparison with the corresponding pre-treated values using Student's paired $t$ test with $\mathrm{p} \leq 0.05$.

In order to investigate the protective effect of trans-RES $(21 \mu \mathrm{M} / \mathrm{L})$ on cadmium-induced cardio toxicity, a group of 10 isolated hearts were pretreated with RES to induce cardio protection $5 \mathrm{~min}$ before $\mathrm{CdCl}_{2}$ application. Table (1) illustrates that pretreatment with RES rectified the decrease in HR induced by $\mathrm{CdCl}_{2}$ and showed a highly significant increase when compared with the corresponding $\mathrm{CdCl}_{2}$ treated group $(p \leq 0.001)$, an increase began from $10 \mathrm{~min}$ and lasted the end of experiments. At the same time, perfusion of isolated toad's hearts with RES before $\mathrm{CdCl}_{2}$ application prevented prolongation of $\mathrm{P}-\mathrm{R}$ interval only at 5,20 and $25 \mathrm{~min}$ $(\mathrm{p} \leq 0.05)$ when compared with the corresponding $\mathrm{CdCl}_{2}$ treated group by Student's unpaired $t$-test as shown in Table (2). Likewise, the data presented in Table 3 demonstrate that pretreatment of isolated hearts with trans-RES abolished the negative inotropic effect induced by $\mathrm{CdCl}_{2}$ and induced a strong positive inotropic effect when compared with the corresponding $\mathrm{CdCl}_{2}$ treated group.

At the same time, RES pretreatment decreased the percentage cardiac disorders incidences caused by $\mathrm{CdCl}_{2}$ such as bradycardia from $70 \%$ to $30 \%$, ST segment elevation (ischemia) from $100 \%$ to $70 \%$ and $\mathrm{R}$ wave decline (negative inotropism) from $90 \%$ to $40 \%$. Traces illustrating cardioprotective effect of RES against ECGs abnormalities induced by $\mathrm{CdCl}_{2}$ are presented in Figures 1 and Figure 2 where RES application could abolish most ECGs abnormalities induced by $\mathrm{CdCl}_{2}$. A group of 15 hearts was pretreated with $\mathrm{CdCl}_{2}$ to induce cardiac toxicity, till the appearance of cardiac abnormalities; RES $(21 \mu \mathrm{M} / \mathrm{L})$ was added to reveal its therapeutic effect against $\mathrm{CdCl}_{2}$. Seven hearts from 15 one exhibited cardiac abnormalities after 10 min, but the others showed cardiac disorders at different times, were chosen to evaluate the therapeutic effect of RES against $\mathrm{CdCl}_{2}$.

Table 4 and Fig. 3 illustrate that application of $\mathrm{CdCl}_{2}$ on the isolated toad's hearts induced a negative chronotropic effect beginning from $15 \mathrm{~min}$ until the end of experiment accompanied by prolongation of P-R interval and reduction in the R-wave amplitude.

Cardiac arrhythmias induced by $\mathrm{CdCl}_{2}$ as well as bradycardia, A-V heart block and negative inotropic effect and ST segment elevation. Perfusion with RES $(21 \mu \mathrm{M})$ after the incidence of the above abnormalities induced by cadmium had no therapeutic effect neither on $\mathrm{CdCl}_{2}$-induced bradycardia nor P-R interval elongation or negative inotropic effect (noticed at 20 and $25 \mathrm{~min}$ ). The amazing thing is the ability of RES to enhance the positive dromotropic effect of $\mathrm{CdCl}_{2}$, which was noticed at 5, 10 and $15 \mathrm{~min}$ after RES perfusion (Table 4).
Figure 4. demonstrates four cases (I, II, III and IV) of therapeutic effect of resveratrol $(21 \mu \mathrm{M} / \mathrm{L})$ after $2 \mathrm{mM} / \mathrm{L}$ cadmium-induced cardiotoxicity, case I shows sinus arrhythmia and AV heart block. The direct perfusion of RES $(21 \mu \mathrm{M})$ on the isolated toad's hearts pretreated with $\mathrm{CdCl}_{2}$, abolished this arrhythmia. Case II shows ventricular extrasystole, reflecting a ventricular focus with enhanced automaticity of the ventricle, as well as inverted P-wave, reflecting ectopic beats. Also, perfusion of RES counteracted this arrhythmia and p-wave abnormality. The surprising thing is the ability of RES to enhance the R-wave amplitude after $\mathrm{CdCl}_{2}$ application, which was obviously noticed in both cases (I and II). Also, case III case IV show that RES had no effect on the two cases either bradycardia or R-wave decline.

Table 5 represent the percentage of incidence of ECGs abnormalities recorded from $\mathrm{CdCl}_{2}$ pre-treated hearts before perfusion of RES. ECGs abnormalities included bradyarrhythmias as well as ST segment and AV block abnormalities ( $\mathrm{n}=7$ /group).

\section{Discussion}

Cadmium is an ubiquitous environmental toxin which may plausibly contribute to cardiovascular diseases (Navas-Acien et al., 2004). The cardiovascular tissues, heart and blood vessels, are significant targets of cadmium toxicity (Kadrabova et al., 1992). These vascular effects contribute to a variety of cardiovascular pathologic conditions including edema, hypertension (Prozialeck et al., 2006) and atherosclerosis (Messner and Bernhard, 2010).

Several studies in experimental animals have proved that oxidative stress is implicated in the toxicity of cadmium (Sarkar et al., 1995; Moustafa et al., 2000; Patra et al., 2011). Cadmium has been associated with multiple mechanisms that tend to promote vascular injury and atherosclerosis. These include the formation of reactive oxygen species, promotion of lipid peroxidation, depletion of glutathione (GSH), disruption of sulfhydryl homeostasis and down-regulation of NO (Moustafa et al., 2000; Navas-Acien et al., 2004; TellezPlaza et al., 2008).

The obtained results in this study revealed the effect of $\mathrm{CdCl}_{2}$ on the heart in vitro, where $2 \mathrm{mM} / \mathrm{L} \mathrm{CdCl}_{2}$ decreased the heart rate by $70 \%$, the power of ventricular contraction by $90 \%$, and on the contrary, increased the conduction time through increasing P-R interval by $100 \%$. These observed effects are in agreement with the reports of the other investigators (Kopp et al., 1983; Nabil et al., 2002; Shemarova et al., 2011). It is worth noting that These effects could be related to cadmium induced alterations of calcium mediated or calcium activated physiological and biochemical pathways, or both, probably through a competition of the metal with calcium for membrane and intracellular sites linked with the contractile systems (Nasu, 1983).

It was evidenced that sinus abnormalities were the most frequent followed by different degrees of $\mathrm{AV}$ blocks were reported after direct administration of isolated toad's heart with $2 \mathrm{~m} \mathrm{M} / \mathrm{L} \mathrm{CdCl}_{2}$. This indicates that toxic myogenic effects on the myocardium are mostly directed to both sinoatrial (SA) and atrioventicular (AV) nodes. These pathologic cases included S-T segment depression, sinus arrhythmia, severe bradycardia, heart block and ectopic beats, which are often a feature of myocardial infarction (Julian et al., 2000).

In addition, Shemarova et al. (2011) indicated a negative inotropic $\mathrm{Cd}^{2+}$ action on frog heart. The decrease of the heart contraction strength under the $\mathrm{Cd}^{2+}$ action seems to be due to 
two causes: first, block of the $\mathrm{Ca}^{2+}$-channels located on the plasma membrane, for which $\mathrm{CdCl}_{2}$ is inhibitor (Shen et al., 2000; Wang et al., 2004; Kocksk'amper et al., 2008). The second cause is mediated by toxic effect on rat heart mitochondria, which was manifested as an increase in ion permeability of the inner mitochondrial membrane, acceleration of the energy-dependent $\mathrm{K}^{+}$transport into the matrix of mitochondria, and inhibition of their respiratory chain (Shemarova et al., 2011).

These observations confirm the direct mechanism of action of $\mathrm{CdCl}_{2}$ on $\mathrm{Ca}^{+2}$ channels. Therefore, antioxidants might be beneficial in the treatment of these abnormalities. RES is a naturally occurring phenolic compound found in grape skins (Jang et al., 1997; Vinson, 1998), where it is widely consumed as a nutritional supplement (Park et al., 2012). It has been suggested that trans-RES is one of the components responsible for the potential benefits of moderate red wine consumption in reducing cardiovascular disease risk (Wu et al., 2001; Zern and Fernandez, 2005; Pineda-Sanabria et al., 2011).

The current study indicates a cardioprotective effect of RES, since pretreatment with $21 \mu \mathrm{M} / \mathrm{L}$ RES ameliorated the negative chrontropic and inotropic effects as well as abnormalities induced by $\mathrm{CdCl}_{2}$ application, where RES perfusion before $\mathrm{CdCl}_{2}$ decreased the percentage of cardiac abnormalities incidence. These results coincide with Rezk et al. (2006) and Zhao et al. (2008) who proved that RES possessed protective effects on $\mathrm{As}_{2} \mathrm{O}_{3}$-induced toxicity in $\mathrm{H} 9 \mathrm{c} 2$ cardiomyocyte cells in vitro and in a mouse model of $\mathrm{As}_{2} \mathrm{O}_{3}$-induced cardiomyopathy in vivo.

The cardioprotective effects of RES have been reported in various in vitro and in vivo studies. In vitro studies have demonstrated that RES is associated with a variety of specific benefits, including reduced platelet aggregation, protection against low-density lipoprotein oxidation and inflammation, and improved plasma lipid profiles, that could collectively contribute to the putative cardioprotective action of this compound (Wu et al., 2001; Zern and Fernandez, 2005). In addition, RES and other red wine polyphenols have vasodilatory effects when applied to isolated artery segments in vitro at pharmacologic concentrations (Chen and PaceAsciak, 1996; Rakici et al., 2005).

Several studies have shown that vascular relaxation was achieved with RES in several vascular beds. RES-induced vessel relaxation was documented in the rat aorta, porcine coronary arteries, guinea-pig mesenteric and uterine arteries and sheep coronary arteries (Chen and Pace-Asciak, 1996; Naderali et al., 2000; El-Mowafy, 2002). These studies indicated that RES exerts both direct and indirect vasodilator effects on the blood vessel by endothelium-independent (nonNO-mediated) and endothelium-dependent (NO-mediated) mechanisms, respectively.

Furthermore, RES exerts cardioprotective effects through NO stimulation in rat hearts during ischemia/reperfusion (Hung et al., 2000, 2001). Subsequently, they also found that RES exerts anti-infarction effects through a NO-dependent mechanism; whereas the antiarrhythmic effects appear to be NO-independent (Hung et al., 2004).

Experimental studies in animal models have shown that grape juice, red wine or isolated polyphenols like flavon, resveratrol and quercetin reduce the contractile dysfunctions of the heart and protect against cellular lesion induced by cardiac ischemia (Sato et al., 2000; Brookes et al., 2002; Cui et al., 2002). These effects may be observed following an oral intake of these substances or after their perfusion in an isolated heart before the induction of an ischemia. Also, RES showed a direct cardioprotective effect in vivo on diabetic myocardium in rats with streptozotocin-induced diabetes by improving left ventricular function, reducing the size of myocardial infarcts, and increasing levels of superoxide dismutase, a powerful antioxidant (Thirunavukkarasu et al., 2007). Another studies showed that RES effectively suppresses ischemia/reperfusion-induced arrhythmia (Hung et al., 2000, 2001; Dernek et al., 2004; Chen et al., 2007) by decreasing the oxidative stress generated in ischemicreprefused myocardium (Ray et al., 1999; Hung et al., 2002).

The current data also revealed that RES post treatment had no significant improvement of the cardiotoxic effects induced by cadmium. This agrees with the study of Hung et al. (2000) they showed that RES was not effective in preventing arrhythmia nor in reducing the mortality rate sustained coronary artery occlusion.

The cardioprotective effect of RES was also attributed to its ability to upregulate catalase activity in the myocardium. RES functions as in vivo antioxidant and can scavenge peroxyl radicals in the heart (Sato et al., 2000a; Shigematsu et al., 2003). and protects the heart from ischemia reperfusion injury (Sato et al., 2000b).

Among its cardioprotective effects, RES was shown to directly affect the contractile function of guinea pig myocytes, where it induced contraction, its relation with the $\mathrm{Ca}^{2+}$ transients was quantitatively determined, indicating an increase in myofilament $\mathrm{Ca}^{2+}$ sensitivity (Liew et al., 2005).

These findings indicate a direct relation between RES and the $\mathrm{Ca}^{2+}$-regulated elements in myocytes; however, the specific mode of its action is unknown. Pineda-Sanabria et al. (2011) indicated that trans-RES act as $\mathrm{Ca}^{2+}$ sensitizer through targeting $\mathrm{C}$-domain of troponin $\mathrm{C}(\mathrm{cCTnC})$. Recently, the polyphenol, propyl gallate, has also been identified to act as a $\mathrm{Ca}^{2+}$ sensitizer with strong antioxidant activity (Tadano et al., 2009), which alongside the functional and structural data for epigallocatechin gallate (EGCg) and RES, points to a common mechanism by which these natural compounds target the thin filament to protect against heart failure.

In conclusion, using an isolated toad's hearts in vitro, the current investigation confirmed the protective effects of resveratrol against $\mathrm{CdCl}_{2}$-induced injury to cardiomyocytes. The obtained results indicate that resveratrol could serve as a protective agent against some of acute cadmium chloride toxicity on isolated toad's heart. Although, resveratrol was not effective in preventing sinus bradycardia nor in reducing ventricular dysfunction after cadmium induced cardiac disorders, it could abolish some cardiac disorders such as arrhythmia and heart block. This is might be explained by the finding of the present work.

\section{References}

Bernhard, D., Rossmann, A., Henderson, B., Kind, M., Seubert, A., Wick, G., 2006. Increased serum cadmium and strontium levels in young smokers: effects on arterial endothelial cell gene transcription. Arteriosclerosis, Thrombosis and Vascular Biology 26(4), 833-838.

Berwe, D., Gottschalk, G., Luttgau, H.C., 1987. Effects of the calcium antagonist gallopamil (D600) upon excitationcontraction coupling in toe Muscle fibers of the frog. J. Physiol. 385, 693-707.

Bhat, K.P.L., Kosmeder, J.W., Pezzuto, J.M., 2001. Biological effects of resveratrol. Antioxid. Redox. Signal. 3, 1041-1064. 
Bhatnagar, A., 2006. Environmental cardiology: studying mechanistic links between pollution and heart disease. Circ. Res. 99(7), 692-705.

Brookes, P.S., Digerness, S.B., Parks, D.A., Darley-Usmar, V., 2002. Mitochondrial function in response to cardiac ischemia-reperfusion after oral treatment with quercetin. Free Radic. Biol. Med. 32, 1220-1228.

Chen, C.K., Pace-Asciak, C.R., 1996. Vasorelaxing activity of resveratrol and quercetin in isolated rat aorta. Gen. Pharmacol. 27, 363-366.

Chen, F., Ding, M., Castranova, V., Shi, X.L., 2001. Carcinogenic metals and NF-kappa B activation. Mol. Cell Biochem. 222, 159-171.

Chen, W.P., Su, M.J., Hung, L.M., 2007. In vitro electrophysiological mechanisms for antiarrhythmic efficacy of resveratrol, a red wine antioxidant. Eur. J. Pharmacol. 554, 196-204.

Chevion, M., 1991. Protection against free radical induced and transition of metal- mediated damage; the use of "pull" and 'push' mechanisms. Free Rad. Res. Comm. 12-13, 691696.

Cui, J., Cordis, G.A., Tosaki, A., Maulik, N., Das, D.K., 2002. Reduction of myocardial ischemia reperfusion injury with regular consumption of grapes. Ann. N Y Acad. Sci. 957, 302-307.

Dernek, S., Ikizler, M., Erkasap, N., Ergun, B., Koken, T., Yilmaz, K., Sevin, B., Kaygisiz, Z., Kural, T., 2004. Cardioprotection with resveratrol pretreatment-improved beneficial effects over standard treatment in rat hearts after global ischemia. Scand. Cardiovasc. J. 38, 245-254.

El-Mowafy, A. M., 2002. Resveratrol activates membranebound guanylyl cyclase in coronary arterial smooth muscle: A novel signaling mechanism in support of coronary protection. Biochem. Biophys. Res. Commun. 291, 1218-1224.

Everett, C.J., Frithsen, I.L., 2008. Association of urinary cadmium and myocardial infarction. Environ. Res. 106(2), 284-286.

Frankel, E.N., Waterhouse, A.L., Kinsella, J.E., 1993. Inhibition of human LDL oxidation by resveratrol. Lancet 341, 1103-1104.

Hancox, J. C., Levi, A. J., 1994. L-type calcium current in rod-shaped and spindle-shaped myocytes isolated from rabbit atrioventricular node. Amer. J. Physiol. Heart and Circ. Physiol. 36, 1670-1680.

Houston, M.C., 2007. The role of mercury and cadmium heavy metals in vascular disease, hypertension, coronary heart disease, and myocardial infarction. Altern. Ther. Health Med. $13, \mathrm{~S} 128-\mathrm{S} 133$.

Houtman, J.P., 1993. Prolonged low-level cadmium intake and atherosclerosis. Sci. Total Environ. 138(1-3), 31-36.

Hsieh, T.C., Juan, G., Darzynkiewicz, Z., Wu, J.M., 1999. Resveratrol increases nitric oxide synthase, induces accumulation of $\mathrm{p} 53$ and $\mathrm{p} 21$, and suppresses cultured bovine pulmonary artery endothelial cell proliferation by perturbing pregression through S to G2. Cancer Res. 59, 2596-2601.

Huang, J.P., Huang, S.S., Deng, J.Y., Chang, C.C., Day, Y.J., Hung, L.M., 2010. Insulin and resveratrol act synergistically, preventing cardiac dysfunction in diabetes, but the advantage of resveratrol in diabetics with acute heart attack is antagonized by insulin. Free Radic. Biol. Med. 49, 1710 1721.

Hung, L.M., Chen, J.K., Huang, S.S., Lee, R.S., Su, M.J., 2000. Cardioprotective effect of resveratrol, a natural antioxidant derived from grapes. Cardiovasc. Res. 47, 549555 .

Hung, L.M., Chen, J.K., Lee, R.S., Liang, H.C., Su, M.J., 2001. Beneficial effects of astringinin, a resveratrol analogue, on the ischemia and reperfusion damage in rat heart. Free Radic. Biol. Med. 30, 877-883.

Hung, L.M., Su, M.J., Chu, W.K., Chiao, C.W., Chan, W.F., Chen, J.K., 2002.The protective effect of resveratrols on ischaemia-reperfusion injuries of rat hearts is correlated with antioxidant efficacy. Br. J. Pharmacol. 135(7), 16271633.

Hung, L.M., Su, M.J., Chen, J.K., 2004. Resveratrol protects myocardial ischemia-reperfusion injury through both NOdependent and NO-independent mechanisms. Free Radic. Biol. Med. 36, 774-781.

Jang, M., Cai, L., Udeani, G.O., Slowing, K.V., Thomas, C.F., Beecher, C.W., Fong, H.H., Farnsworth, N.R., Kinghorn, A. D., Mehta, R.G., Moon, R.C., Pezzuto, J. M., 1997. Cancer chemopreventative activity of resveratrol, a natural product derived from grapes. Science 275, 218-220.

Juberg, D., Stuenkel, E., Loch-Caruso, R., 1995. The chlorinated insecticide 1,1-dichloro-2,2bis(4chlorophenyl)ethane (p,p'-DDD) increases intracellular calcium in rat myometrial smooth muscle cells. Toxicol. Appl. Pharmacol. 135, 147-155.

Julian, D., Cowan, J., Mclenachan, J., 2000. Heart failure In: "Cardiology" International Edition, Harcourt Publishers Ltd. North Youkshire, China 129-153.

Kadrabova, J., Madaric, A., Ginter, E., 1992. The effect of ascorbic acid on cadmium accumulation in guinea pig tissues. Experientia. 48, 989-991.

Kisling, G.M., Kopp, S.J., Paulson, D.J., Tow, J.P., 1993. Cadmium-induced attenuation of coronary blood flow in the perfused rat heart. Toxicol. Appl. Pharmacol. 118, 58-64.

Kocksk'amper, J., Zima, A.V., Roderick, H.L., Pies ke, B., Blatter, L.A., Bootman, M.D., 2008. Emerging roles of inositol 1,4,5-trisphosphate signaling in cardiac myocytes. J. Mol. Cell Cardiol. 45, 128-147.

Kopp, S.J., Perry, H.M., Perry, E.F., Erlanger, M., 1983. Cardiac physiologic and tissue metabolic changes following chronic low-level cadmium and cadmium plus lead ingestion in the rat. Toxicol. Appl. Pharmacol. 69, 149-160. 
Korotkov, S.M., Nesterov, V.P., Ryabchikov, N.N., 2008. About effect of SH-groups on the mitochondrial respiration and swelling in rat heart, Dokl RAN 421, 123-127.

Liew, R., Stagg, M. A., MacLeod, K. T., Collins, P., 2005. The red wine phenol, resveratrol, exerts acute direct action on guinea-pig ventricular myocytes. Eur. J. Pharmacol. 519, 1-8.

Messner, B. and Bernhard, D., (2010).Cadmium and cardiovascular diseases: cell biology, pathophysiology, and epidemiological relevance. Bio Metals 23 (5), 811-822.

Moustafa, S.A., Nabil, Z.I., Ahmed, S.H., 2000. Protective effect of zinc against cadmium toxicity. Res. Comm. Pharmacol. Toxicol. 5(5), 3-4.

Nabil, Z., Hussein, A., Zalat, S., Rakha, M., 1998. Mechanism of action of honey bee (Apis mellifera L.) venom on different types of muscles. Human and Experimental Toxicology 17, 185-190.

Nabil, Z.I., Moustafa, S.A., Ahmed, S.H., 2002. Effect of cadmium toxicity on cardiac and smooth muscles mechanism and protection. J. Egypt Ger. Soc. Zool. 38A, 1-21.

Naderali, E. K., Doyle, P. J., Williams, G., 2000. Resveratrol induces vasorelaxation of mesenteric and uterine arteries from female guinea pigs. Clin. Sci. 98, 537-543.

Nasu, T., 1983 . Spasmolitic effect of cadmium and cadmium uptake in aorta. Br. J. Pharmacol. 79, 751-754.

Navas-Acien, A., Selvin, E., Sharrett, A.R., Calderon-Aranda, E., Silbergeld, E., Guallar, E., 2004. Lead, cadmium, smoking, and increased risk of peripheral arterial disease. Circulation 109, 3196-3201

Navas-Acien, A., Silbergeld, E.K., Sharrett, R., CalderonAranda, E., Selvin, E., Guallar, E., 2005. Metals in urine and peripheral arterial disease. Environ Health Perspect. 113(2), 164-169.

Olas, B., Wachowicz, B., Saluk-Juszczak, J., Zielinski, T., 2002. Effect of resveratrol, a natural polyphenolic compound, on platelet activation induced by endotoxin or thrombin. Thromb. Res. 107, 141-145.

Park, Sung-Jun; Ahmad, F., Philp, A., Baar, K., Williams, T., Luo, H., Ke, H., Rehmann, H., Taussig, R., Brown, A. L., Kim, M. K., Beaven, M. A., Burgin, A. B., Manganiello, V., Chung, J. H., 2012. Resveratrol Ameliorates Aging-Related Metabolic Phenotypes by Inhibiting cAMP Phosphodiesterases. Cell 148, 421-433.

Patra, C., Rautray, A. K., Swarup, D., 2011: Oxidative Stress in Lead and Cadmium Toxicity and Its Amelioration. Veterinary Medicine International.

Pervaiz S., 2003. Resveratrol: from grapevines to mammalian biology. FASEB J. 17, 1975-1985.

Pineda-Sanabria, S. E., Robertson, I. M., Sykes, B. D., 2011. Structure of trans-Resveratrol in Complex with the Cardiac Regulatory Protein Troponin C. Biochemistry 50, 1309-1320.

Prozialeck, W. C., Edwards, J. R., Woods, J. M., 2006. The vascular endothelium as a target of cadmium toxicity. Life Sci, 79, 1493-1506.
Rakici, O., Kiziltepe, U., Coskun, B., Aslamaci, S., Akar, F., 2005. Effects of resveratrol on vascular tone and endothelial function of human saphenous vein and internal mammary artery. In. J. Cardiol. 105, 209-215.

Ray, P. S., Maulik, G., Cordis, G. A., Bertelli, A. A., Bertelli, A., Das, D. K., 1999. The red wine antioxidant resveratrol protects isolated rat hearts from ischemia reperfusion injury. Free Radic. Biol. Med. 27, 160-169.

Rezk, Y.A., Balulad, S.S., Keller, R.S., Bennett, J.A., 2006. Use of resveratrol to improve the effectiveness of cisplatin and doxorubicin: study in human gynecologic cancer cell lines and in rodent heart. Am. J. Obstet. Gynecol. 194, e23-e26.

Sarkar, S., Yadar, P., Trivedi, R., Bansal, A.K., Bhatnagar, D., 1995. Cadmium-induced lipid peroxidation and the status of the antioxidant system in rat tissues. J. Trace Elem. Med. Biol. 9, 144-149.

Satarug, S., Nishijo, M., Lasker, J.M., Edwards, R.J., Moore, M.R. 2006. Kidney dysfunction and hypertension: role for cadmium, p450 and heme oxygenases? Tohoku J. Exp. Med. 208,179-202.

Sato, M., Ray, P. S., Meulki, G., Meulki, N., Engelman, R. M., Bertelli, A. A. E., Das, D. K., 2000. Myocardial protection with red wine extract. J. Cardiovas. Pharmacol. 35, 263-268.

Sato, M., Cordis, G.A., Maulik, N., Das, D.K., 2000a. SAPKs regulation of ischemic preconditioning. Am. J. Physiol. 279, H901-H907.

Sato, M., Maulik, G., Bagchi, D., Das, D.K., 2000 b. Myocardial protection by protykin, a novel extract of transresveratrol and emodin. Free Radic. Res. 32, 135-144.

Shemarova, I. V., Korotkov, S. M., Nesterov, V. P., 2011. Effect of oxidative processes in mitochondria on contractility of heart muscle of the frog Rana temporaria. Actions of $\mathrm{Cd}^{2+}$. J. Evolutionary Biochem. Physiol. 47, 360-365.

Shen, J.B., Jiang, B., Pappano, A.J., 2000. Comparison of LType calcium channel blockade by nifedipine and/or cadmium in guinea pig ventricular myocytes. J. Pharmacol. Exp. Ther. 294, 562-570.

Shigematsu, S., Ishida, S., Hara, M., Takahashi, N., Yoshimatsu, H., Sakata, T., Korthuis, R.J., 2003. Resveratrol, a red wine constituent polyphenol, prevents superoxidedependent inflammatory responses induced by ischemia/reperfusion, platelet-activating factor, or oxidants. Free Radic. Biol. Med. 34(7):810-817.

Snedecor, G. w., Cochran, W.G., 1980 . Statistical methods. $7^{\text {th }}$ ed. Iowa State Univ. Press, U.S.A.

Tadano, N., Morimoto, S., Takahashi-Yanaga, F., Miwa, Y., Ohtsuki, I., Sasaguri, T., 2009. Propyl Gallate, a Strong Antioxidant, Increases the $\mathrm{Ca}^{2+}$ Sensitivity of Cardiac Myofilament. J. Pharmacol. Sci. 109,456-458.

Tellez - Plaza, M., Navas - Acien, A., Crainiceanu, C.M., Guallar, E., 2008. Cadmium exposure and hypertension in the 1999 - 2004 National Health and Nutrition Examination Survey (NHANES). Environ. Health Perspect. 116, 51 - 56. Thandapilly, S.J., Wojciechowski, P., Behbahani, J., Louis, 
X.L., Yu, L., Juric, D., Kopilas, M.A., Anderson, H.D., Netticadan, T., 2010. Resveratrol prevents the development of pathological cardiac hypertrophy and contractile dysfunction in the SHR without lowering blood pressure. Am. J. Hypertens. 23, 192-196.

Thirunavukkarasu, M., Penumathsa, S.V., Koneru, S., Juhasz, B., Zhan, L., Otani, H., Bagchi, D., Das, D.K., Maulik, N., 2007. Resveratrol alleviates cardiac dysfunction in streptozotocin-induced diabetes: Role of nitric oxide, thioredoxin, and heme oxygenase. Free Radic. Biol. Med. 43, 720-729.

Vinson, J.A., 1998. Flavanoids in foods as in vitro and in vivo antioxidants. Adv. Exp. Med. Biol. 439, 151-164.

Wallerath, T., Deckert, G., Ternes, T., Anderson, H., Li, H., Witte, K., Forstermann, U., 2002 . Resveratrol, a polyphenolic phytoalexin present in red wine, enhances expressionand activity of endothelial nitric oxide synthase. Circulation 106, 1652-1658.

Wang, X., Evans, C., Mendelowitz, D., 2004. Voltage gated $\mathrm{P} / \mathrm{Q}$ and $\mathrm{N}$-type calcium channels mediate the nicotinic facilitation of GABAergic and glycinergic Inputs to cardiac vagal neurons. Neuropharmacol. 46, 372-378.
Wasserstrom, J.A., Vites, A.M., 1999. Activation of contraction in cat ventricular myocytes: Effects of Low $\mathrm{Cd}^{2+}$ concentration and temperature. Am. J. Physiol. 277, H488H498.

Weinhold, B., 2004. Environmental cardiology: getting to the heart of the matter. Environ. Health Perspect. 112(15), A880A887.

Wiedmann, R. T., Tan, R. C., Joyner, R. W., 1996 .Discontinuous conduction at Purkinje-ventricular muscle junction. Am. J. Physiol. Heart Circ. Physiol. 271 (4), H1507H1516.

Wu, J.M., Wang, Z.R., Hsieh, T.C., Bruder, J. L., Zou, J.G., Huang, Y.Z., 2001. Mechanism of cardioprotection by resveratrol, a phenolic antioxidant present in red wine. Intl. J. Mol. Med. 8, 3-17.

Zern, T.L., Fernandez, M. L., 2005. Cardioprotective effects of dietary polyphenols. J. Nutr. 135, 2291-2294.

Zhao, X.Y., Li, G.Y., Liu, Y., Chai, L.M., Chen, J.X., Zhang, Y., Du, Z.M., Lu, Y.J., Yang, B.F., 2008. Resveratrol protects against arsenic trioxide-induced cardiotoxicity in vitro and in vivo. Br. J. Pharmacol. 154, 105-113.

Table 1. Effect of direct perfusion with $21 \mu \mathrm{M} / \mathrm{L}$ resveratrol and $2 \mathrm{mM} / \mathrm{L} \mathrm{CdCl}_{2}$ on the HR of isolated toad hearts.

\begin{tabular}{|c|c|c|c|}
\hline \multicolumn{4}{|c|}{ Heart Rate (beat/min.) } \\
\hline TIME & Ringer (I) & $\mathrm{CdCl}_{2}$ (II) & $\mathrm{RES}+\mathrm{CdCl}_{2}(\mathrm{III})$ \\
\hline 0 min & $52.1 \pm 1.5$ & $54.13 \pm 1.4$ & $57.4 \pm 2.3$ \\
\hline $5 \mathrm{~min}$ & $54.86 \pm 1.45$ & $50.3 \pm 1.7^{\text {a b }}$ & $56.6 \pm 2.2^{¥}$ \\
\hline $10 \mathrm{~min}$ & $53.05 \pm 1.06$ & $47.1 \pm 2.08^{a b}$ & $54.5 \pm 2.05^{¥}$ \\
\hline $15 \mathrm{~min}$ & $53.67 \pm 2.17$ & $44.3 \pm 2.4^{\mathrm{ab}}$ & $51.9 \pm 1.6^{¥}$ \\
\hline $20 \mathrm{~min}$ & $44.54 \pm 1.89^{a}$ & $39.2 \pm 2.6^{\mathrm{a}}$ & $50.3 \pm 1.7^{a ¥}$ \\
\hline $25 \mathrm{~min}$ & $43.49 \pm 2.34^{\mathrm{a}}$ & $31.4 \pm 2.6^{\mathrm{a} b}$ & $48.2 \pm 1.5^{a ¥}$ \\
\hline 30min & $42.81 \pm 2.11^{a}$ & $28.05 \pm 2.9^{a b}$ & $44.7 \pm 2.9$ a¥ \\
\hline
\end{tabular}

Table 2. Effect of direct perfusion with $21 \mu \mathrm{M} / \mathrm{L}$ resveratrol and $2 \mathrm{mM} / \mathrm{L} \mathrm{CdCl}_{2}$ on the P-R interval of isolated toad hearts.

\begin{tabular}{|c|c|c|c|}
\hline \multicolumn{4}{|c|}{ P-R (msec.) } \\
\hline TIME & Ringer (I) & $\mathrm{CdCl}_{2}$ (II) & $\mathrm{RES}+\mathrm{CdCl}_{2}(\mathrm{III})$ \\
\hline Omin & $280 \pm 17$ & $305 \pm 8.9$ & $310 \pm 24.5$ \\
\hline $5 \mathrm{~min}$ & $350 \pm 18.26^{a}$ & $390 \pm 19.4^{a}$ & $320 \pm 27^{¥}$ \\
\hline $10 \mathrm{~min}$ & $400 \pm 14.9^{a}$ & $445 \pm 11.7^{\text {a b }}$ & $410 \pm 33.2^{\mathrm{a}}$ \\
\hline
\end{tabular}




\begin{tabular}{cccc}
\hline $15 \mathrm{~min}$ & $425 \pm 26.08^{\mathrm{a}}$ & $515 \pm 22.4^{\mathrm{a} \mathrm{b}}$ & $445 \pm 43.1^{\mathrm{a}}$ \\
\hline $20 \mathrm{~min}$ & $540 \pm 28.7^{\mathrm{a}}$ & $635 \pm 36.6^{\mathrm{a} \mathrm{b}}$ & $505 \pm 37.6^{\mathrm{a}}$ \\
$25 \mathrm{~min}$ & $555 \pm 31.1^{\mathrm{a}}$ & $690 \pm 36.4^{\mathrm{a} \mathrm{b}}$ & $530 \pm 42.3^{\mathrm{a}}$ \\
$30 \mathrm{~min}$ & $580 \pm 35.9^{\mathrm{a}}$ & $720 \pm 39.6^{\mathrm{a} \mathrm{b}}$ & $605 \pm 62.1^{\mathrm{a}}$ \\
\hline
\end{tabular}

Table 3. Effect of direct perfusion with $21 \mu \mathrm{M} / \mathrm{L}$ resveratrol and $2 \mathrm{mM} / \mathrm{L} \mathrm{CdCl}_{2}$ on the depolarization voltage ( $R$-wave amplitude) of isolated toad's heart.

\begin{tabular}{|c|c|c|c|}
\hline \multicolumn{4}{|c|}{ R-amplitude (mv) } \\
\hline TIME & Ringer (I) & $\mathrm{CdCl}_{2}$ (II) & $\mathrm{RES}+\mathrm{CdCl}_{2}(\mathrm{III})$ \\
\hline Omin & $1.46 \pm 0.06$ & $1.47 \pm 0.08$ & $1.51 \pm 0.06$ \\
\hline $5 \mathrm{~min}$ & $1.62 \pm 0.09$ & $1.37 \pm 0.14$ & $2.22 \pm 0.17^{\text {a } ¥}$ \\
\hline $10 \mathrm{~min}$ & $1.68 \pm 0.11$ & $1.36 \pm 0.14^{b}$ & $2.08 \pm 0.14^{\mathrm{a} ¥}$ \\
\hline $15 \mathrm{~min}$ & $1.76 \pm 0.22$ & $1.28 \pm 0.12 \mathrm{~b}$ & $1.85 \pm 0.17^{\text {a } ¥}$ \\
\hline 20min & $1.65 \pm 0.21$ & $1.24 \pm 0.14$ & $1.62 \pm 0.19^{a}$ \\
\hline 25min & $1.43 \pm 0.2$ & $0.98 \pm 0.13^{\text {a b }}$ & $1.62 \pm 0.20^{¥}$ \\
\hline 30min & $1.23 \pm 0.2$ & $0.71 \pm 0.1^{\text {a b }}$ & $1.23 \pm 0.15^{¥}$ \\
\hline
\end{tabular}

Values expressed as mean $\pm \mathrm{SE}$ ( $\mathrm{n}=10$ /group).

${ }^{a}$ Significantly different between self control ( 0 - time) and treated groups $(5,10,15,20,25 \& 30 \mathrm{~min})$ using Student's paired $t$-test $(\mathrm{p} \leq 0.05)$.

${ }^{\mathrm{b}}$ Significantly different from the control group (group I), Student's unpaired $t$-test $(\mathrm{p} \leq 0.05)$.

${ }^{*}$ Significantly different by Student's unpaired $t$-test, $\mathrm{CdCl}_{2}$ versus Res $+\mathrm{CdCl}_{2}(\mathrm{p} \leq 0.05)$.

0 min, before any treatment; 5, 10, 15, 20, 25 and $30 \mathrm{~min}$ (I and II groups), after Ringer and $\mathrm{CdCl}_{2}$ perfusion into isolated toad's heart; 5, 10, 15, 20, 25 and $30 \mathrm{~min}$ (III group), after application of $\mathrm{CdCl}_{2}$ of RES pre-treated hearts.

Table 4. Therapeutic effect of $21 \mu \mathrm{M} / \mathrm{L}$ resveratrol after $2 \mathrm{mM} / \mathrm{L} \mathrm{CdCl}_{2}$ application on the heart rate (HR), conduction velocity (P-R interval) and depolarization voltage (Ramplitude) of isolated toad's heart.

\begin{tabular}{|c|c|c|c|c|c|c|}
\hline \multirow{2}{*}{ Time } & \multicolumn{2}{|c|}{ HR(beat/min) } & \multicolumn{2}{|c|}{ P-R (msec) } & \multicolumn{2}{|c|}{ R-amplitude (mv) } \\
\hline & $\mathrm{CdCl}_{2}(\mathrm{I})$ & $\mathrm{CdCl}_{2}+\mathrm{RES}(\mathrm{II})$ & $\mathrm{CdCl}_{2}(\mathrm{I})$ & $\mathrm{CdCl}_{2}+\mathrm{RES}(\mathrm{II})$ & $\mathrm{CdCl}_{2}$ (I) & $\mathrm{CdCl}_{2}+\mathrm{RES}(\mathrm{II})$ \\
\hline Omin & $49.17 \pm 2.6$ & $51.73 \pm 2.07$ & $375.7 \pm 17.08$ & $407 \pm 25.42$ & $1.4 \pm 0.07$ & $1.73 \pm 0.15$ \\
\hline $5 \mathrm{~min}$ & $48.03 \pm 1.5$ & $39.78 \pm 3.4$ & $425 \pm 11.2^{a}$ & $600 \pm 52.33^{¥}$ & $1.33 \pm 0.18$ & $1.54 \pm 0.13$ \\
\hline $10 \mathrm{~min}$ & $43.8 \pm 1.4$ & $37.08 \pm 4.14$ & $483.3 \pm 10.5^{a}$ & $671 \pm 68.01^{¥}$ & $1.3 \pm 0.12$ & $1.33 \pm 0.15$ \\
\hline
\end{tabular}




\begin{tabular}{r|cccccc}
\hline $15 \mathrm{~min}$ & $40.91 \pm 2.3^{\mathrm{a}}$ & $30.54 \pm 4.65$ & $550 \pm 18.3^{\mathrm{a}}$ & $728 \pm 73.08^{¥}$ & $1.2 \pm 0.13$ & $1.13 \pm 0.15$ \\
$20 \mathrm{~min}$ & $35.5 \pm 2.4^{\mathrm{a}}$ & $27.68 \pm 4.8$ & $666.7 \pm 57.25$ & $800 \pm 70.71$ & $1.04 \pm 0.12^{\text {a }}$ & $0.9 \pm 0.13$ \\
$25 \mathrm{~min}$ & $27.44 \pm 2.2^{\mathrm{a}}$ & $26.56 \pm 4.7$ & $741.75 \pm 43.6$ & $829 \pm 76.26$ & $0.8 \pm 0.1^{\mathrm{a}}$ & $0.91 \pm 0.15$ \\
\hline
\end{tabular}

Values expressed as mean $\pm \mathrm{SE}$ ( $\mathrm{n}=7$ /group).

a Significantly different between self control ( 0 - time) and treated groups $(5,10,15,20 \& 25 \mathrm{~min})$ using Student's paired t-test $(\mathrm{p} \leq 0.05)$.

$¥$ Significantly different by student's unpaired t-test, $\mathrm{CdCl} 2$ versus $\mathrm{CdCl} 2+\mathrm{Res}(\mathrm{p} \leq 0.02)$.

$0 \mathrm{~min}$, before any treatment; 5, 10, 15, $20 \& 25 \mathrm{~min}$ (I group), after $\mathrm{CdCl} 2$ perfusion into isolated toad's heart; 5, 10, 15, $20 \& 25 \mathrm{~min}$ (II group), after RES perfusion after $10 \mathrm{~min}$ of abnormalities appearance induced by $\mathrm{CdCl} 2$.

Table 5. Percentage of ECGs abnormalities Incidence recorded from $2 \mathrm{mM} / \mathrm{LCdCl} 2$ and 21 $\mu \mathrm{M} / \mathrm{L}$ of resveratrol after $\mathrm{CdCl}_{2}$ on isolated toad's heart $(n=7)$.

Percentage of cardiac abnormalities Incidence (\%)

\begin{tabular}{lcc}
\hline ECG Abnormalities & $\mathbf{C d C l}_{2}$ & $\mathbf{C d C l}_{2}+\mathbf{R E S}$ \\
\hline (A) Abnormal sinus rhythm: & & \\
- Bradycardia & $71 \%$ & $71 \%$ \\
- Ischemia & $100 \%$ & $85 \%$ \\
- Sinus arrhythmia & $43 \%$ & $28 \%$ \\
- R wave decline & $85 \%$ & $85 \%$ \\
(B) Atrioventricular block: & & \\
- First degree & $100 \%$ & $85 \%$ \\
- Second degree & $14 \%$ & $14 \%$ \\
- Complete block & - & - \\
\hline \hline
\end{tabular}



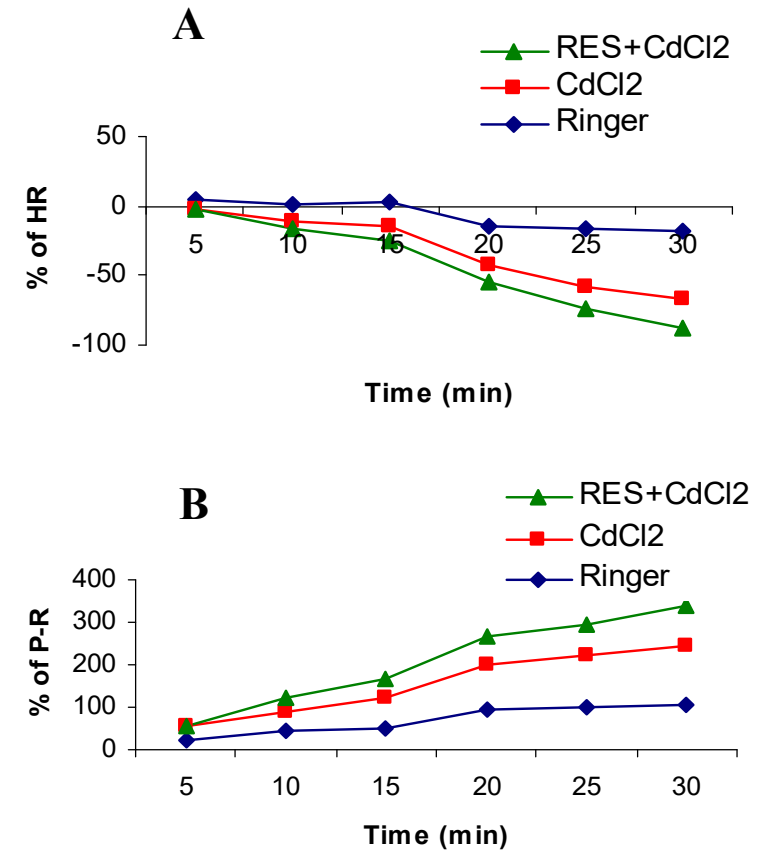

h
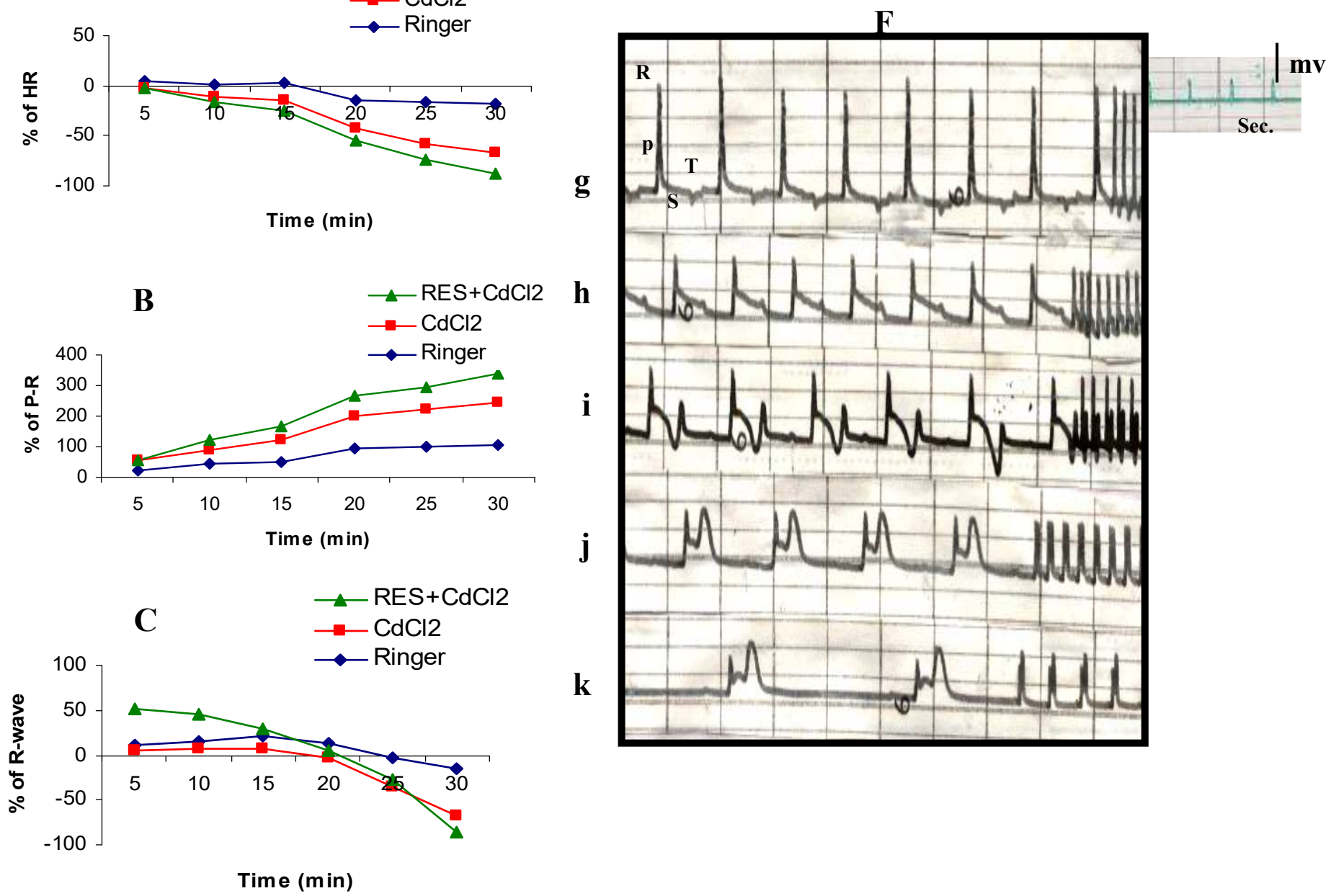

Figure 1. Percent of change of (A) heart rate, (B) P-R interval and (C) R-amplitude of isolated toad's heart after perfusion of RES and $\mathrm{CdCl}_{2}$. (F) ECG traces showing the effect of direct application of isolated toad's heart with $2 \mathrm{mM} / \mathrm{L} \mathrm{CdCl}_{2}$ on the ECG isolated toad's heart at different time intervals. g- Before treatment. h, I, j and k- after 5, 10, 20 and 30 min after $\mathrm{CdCl}_{2}$ application ( $\mathrm{n}=10 /$ group). 
Sec.

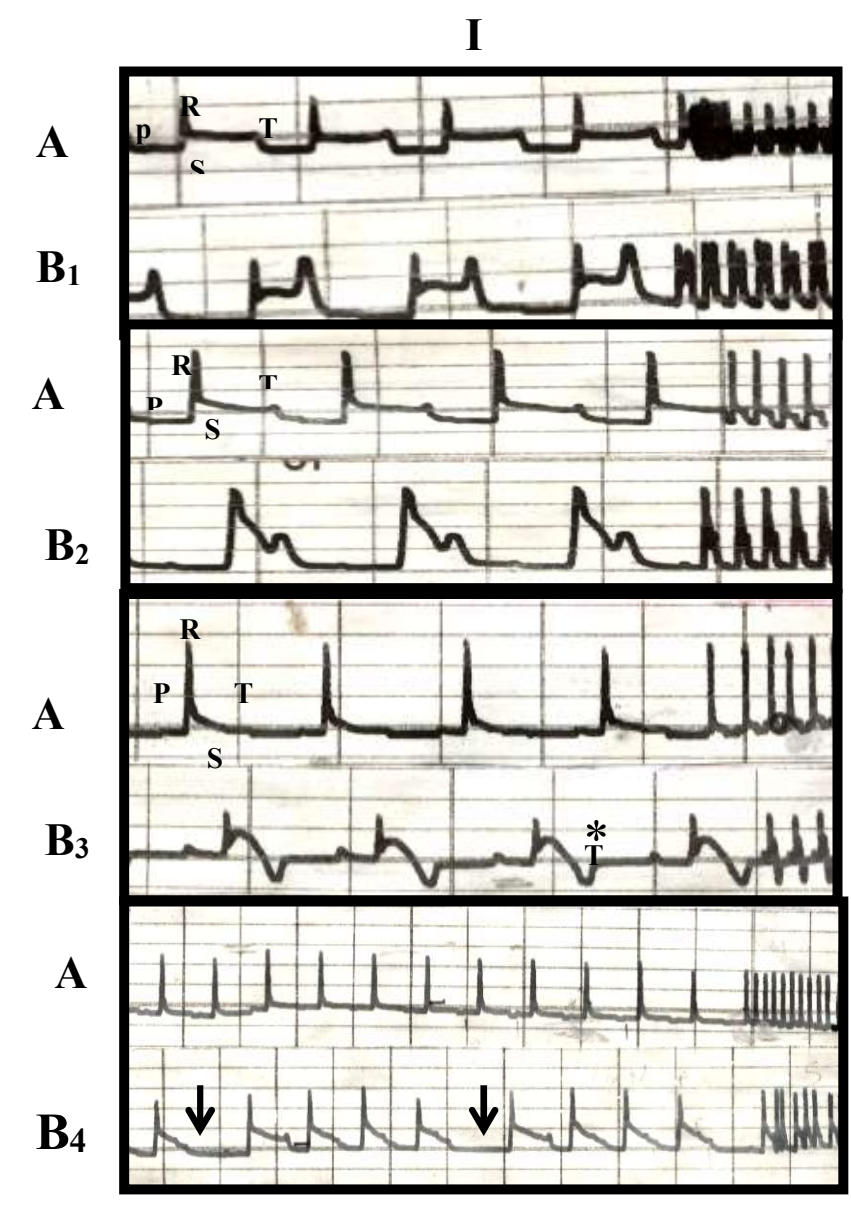

$\mathbf{A}$

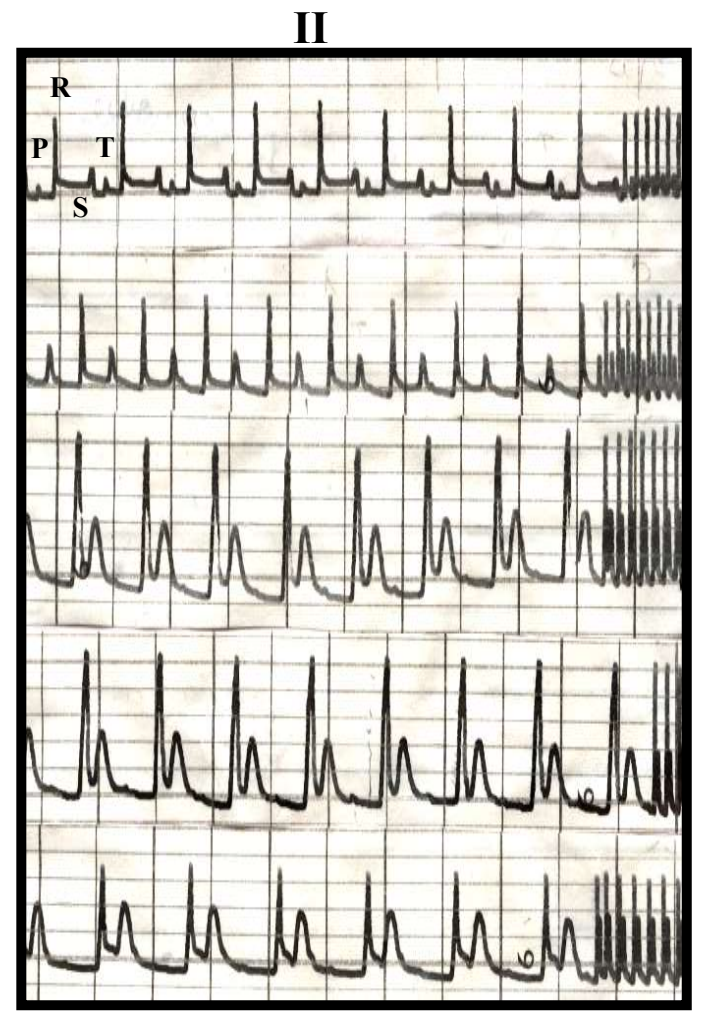

Figure 2. I- ECGs recorders showing examples of cardiac disorders induced by direct application of isolated toad's heart with $2 \mathrm{~m} \mathrm{M} / \mathrm{L}$ of cadmium chloride. A-Before treatment, BAfter treatment, $\mathrm{B}_{1}$ - Ischemia (S-T segment elevation), $\mathrm{B}_{2}-\mathrm{QRS}$ Widen, $\mathrm{B}_{3}-{ }^{*} \mathrm{ST}$ segment depression, $\mathrm{B}_{4}$ - Sinus arrhythmia $(\downarrow)$,. II- ECG traces showing the protective of direct perfusion of isolated toad's heart with $21 \mu \mathrm{M} / \mathrm{L}$ resveratrol against $\mathrm{CdCl}_{2}$ on the ECG isolated toad's heart at different time intervals. A- Before treatment. (B, C, D and E; 5, 10, 20 and 30 min after $\mathrm{CdCl}_{2}$ application of RES pre-treated hearts, respectively) 


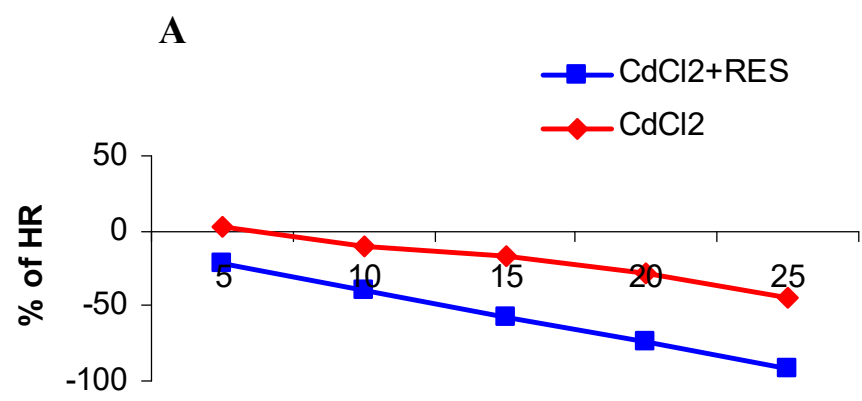

Time (min)
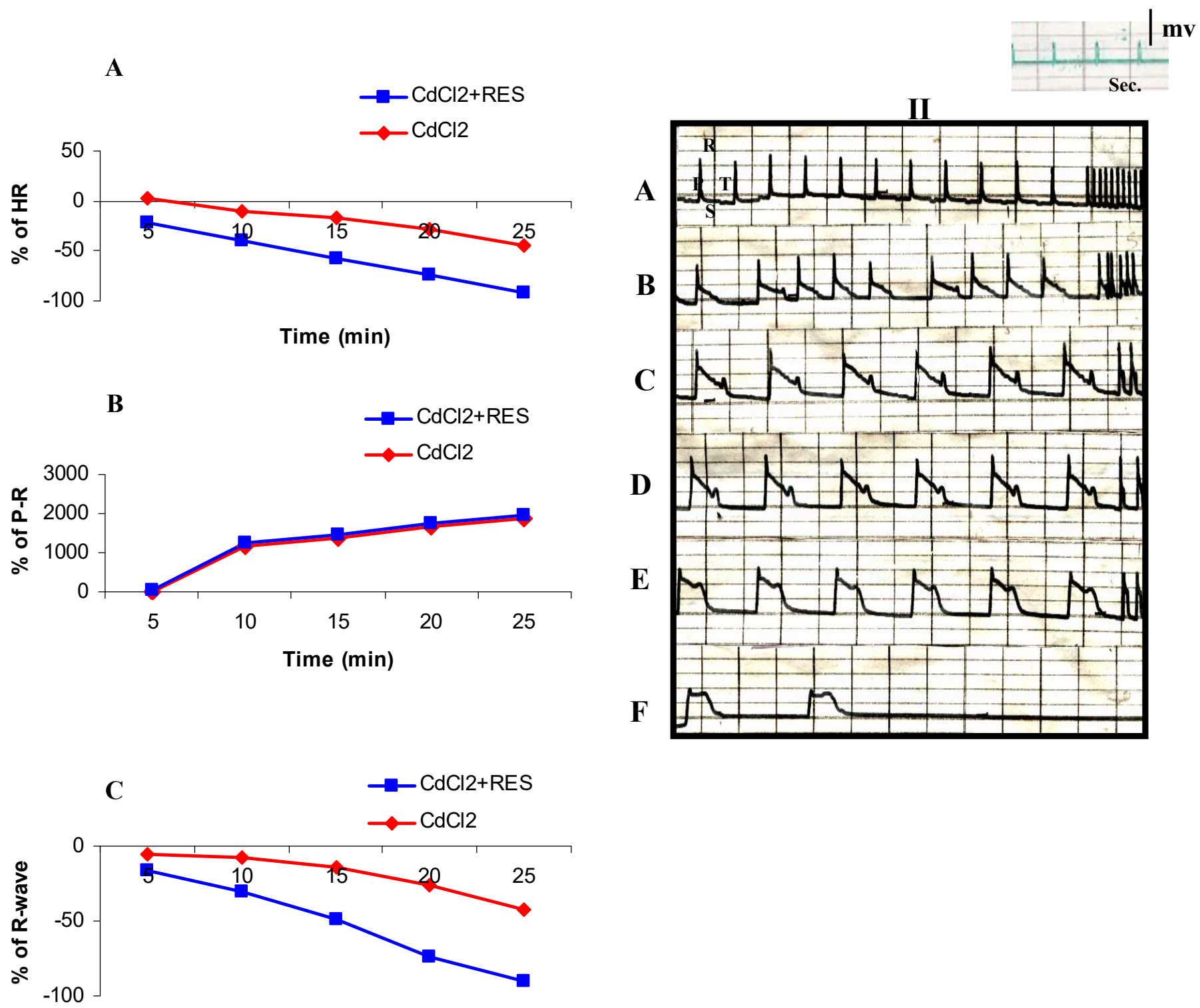

Time (min)

Figure 3. I- Percent of change of (A) heart rate, (B) $P-R$ interval and (C) R-wave of therapeutic effect of RES against $\mathrm{CdCl}_{2}$ pretreated toad's heart ( $\mathrm{n}=7 /$ group).

II- therapeutic effects of direct perfusion of isolated toad's heart with $21 \mu \mathrm{M} / \mathrm{L}$ resveratrol against $\mathrm{CdCl}_{2}$ on the ECG isolated toad's heart at different time intervals.. Trace A-Before treatment; trace B- 5 min after $\mathrm{CdCl}_{2}$ application; traces $\mathrm{C}, \mathrm{D}, \mathrm{E}$ and $\mathrm{F}$ are 5, 10, 20 and $30 \mathrm{~min}$ from RES perfusion after appearance of abnormalities induced by $\mathrm{CdCl}_{2}$. 
A

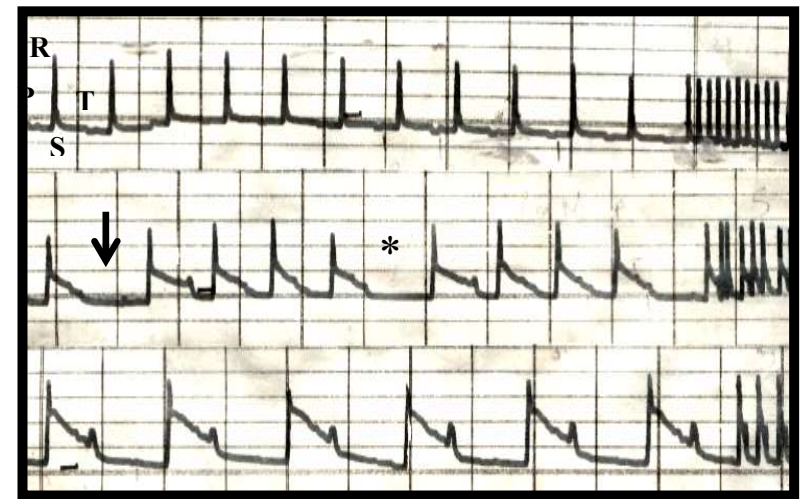

II

A

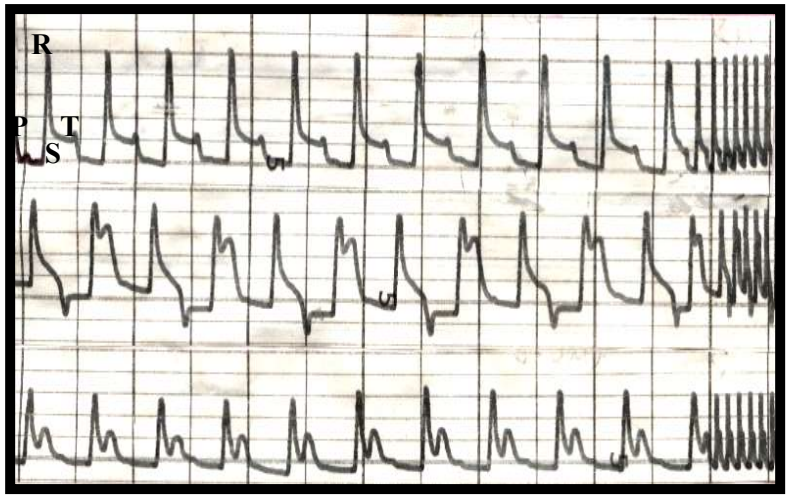

A

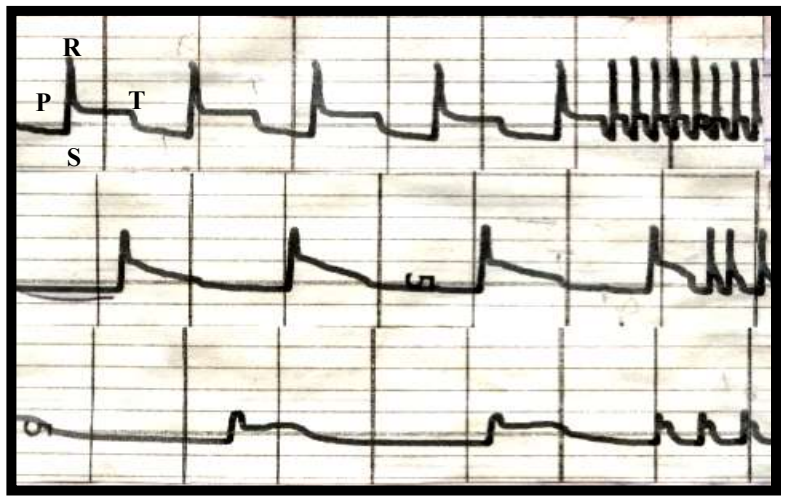

A

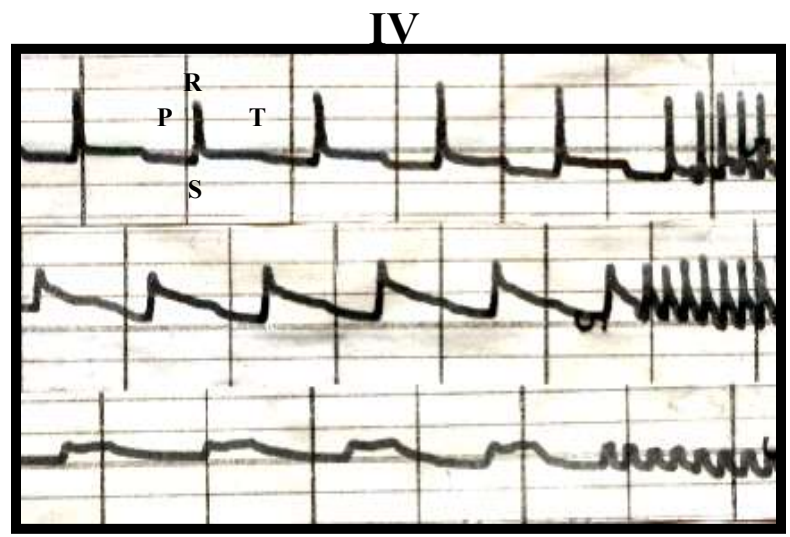

Figure 4. ECG traces showing the therapeutic effect of resveratrol $(21 \mu \mathrm{M} / \mathrm{L})$ after $\mathrm{CdCl}_{2}$ $(2 \mathrm{mM} / \mathrm{L})$ application of isolated toad's.

A- Before treatment.

B- After $\mathrm{CdCl}_{2}$ application

C- After resveratrol perfusion.

I - Sinus arrhythmia (arrow) \& AV block (*)

II -Ventricular extra systole with inverted P- wave.

III - Bradycardia

IV-ST elevation and R-wave decline. 


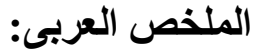

الريسفيراترول من الفلافونيدات الموجودة بكثرة فى العنب و الذى بستخدم كمقاوم للشو ارد الحرة ومضاد للأكسدة وله ناثير نافع على امر اض القب التاجية. تهدف الدراسة الى توضيح التاثير الوقائى والعلاجى للريسفير اترول على تأثير الكادميوم السام على القلب المفصول للضفدعة.

تم تسجيل رسم القلب قبل وبعد اضافة كلوريد الكادميوم و الريسفير اترول. اضافة الكادميوم (2 ملى مولر / لتر) على القلب المفصول ادى الى تناقص معنوى فى معدل نبضات القلب و التى مرتبطة بزيادة قى وقت التوصيلية . كما ادى الى تناقص غير معنوى فى قوة انقباض البطين(R-wave amplitude ). كما ظهرت بعض التغيرات فى رسم القلب بعد اضافة كلوريد

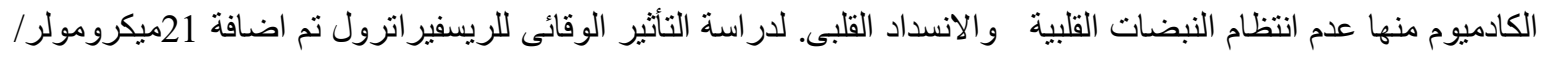

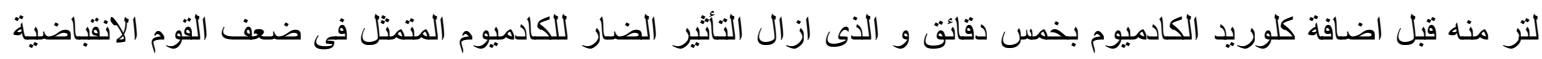

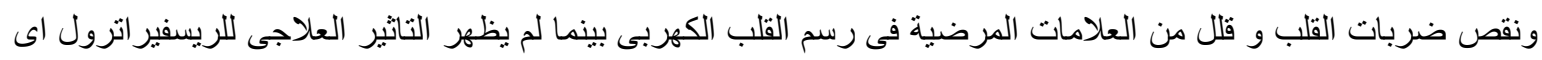
تحسن فى تغير بعض المعايير الالكتروفسيولوجية مثل معدل نبضات القلب و قوة البطين الانقباضية ـو و نتيجة لذلك فان الريسفيراترول قد يكون له تاثير وقائى على السمية القلبية لكلوريد الكادميوم أكثر من التاثير العلاجى له حيث انه لم يمنع تناقص ضربات القلب وضعف قوة البطين الانقباضية المستحدثة باضافة الكادميوم. 